\title{
Artificial radionuclides in neon flying squid from the northwestern Pacific in 2011 following the Fukushima accident
}

\author{
Wen Yu${ }^{1}$, Mathew P. Johansen ${ }^{2}$, Jianhua He ${ }^{1}, W_{\text {Men }}{ }^{1}$, and Longshan Lin ${ }^{1}$ \\ ${ }^{1}$ Third Institute of Oceanography, State Oceanic Administration of China, Xiamen, China \\ ${ }^{2}$ Australian Nuclear Science and Technology Organization, Sydney, Australia \\ Correspondence: Wen Yu (yuwen@tio.org.cn) \\ Received: 16 March 2018 - Discussion started: 8 May 2018 \\ Revised: 24 October 2018 - Accepted: 6 November 2018 - Published: 5 December 2018
}

\begin{abstract}
In order to better understand the impact of the Fukushima Daiichi Nuclear Power Plant (FDNPP) accident on a commercial marine species, neon flying squid $(\mathrm{Om}$ mastrephes bartramii) samples obtained from the northwestern Pacific in November 2011 were analyzed for a range of artificial and natural radionuclides (Cs-134, Cs-137, Ag110m, U-238, Ra-226, and K-40). Short-lived radionuclides Cs-134 and Ag-110m released from the FDNPP accident were found in the samples, with an extremely high waterto-organism concentration ratio for Ag- $110 \mathrm{~m}\left(>2.9 \times 10^{4}\right)$. While accident-derived radionuclides were present, their associated dose rates for the squid were far lower than the relevant benchmark of $10 \mu \mathrm{Gy} \mathrm{h}^{-1}$. For human consumers ingesting these squid, the dose contribution from natural radionuclides, including Po-210, was far greater (>99.9\%) than that of Fukushima-accident radionuclides $(<0.1 \%)$. The whole-body to tissue and whole-body to gut concentration ratios were calculated and reported, providing a simple method to estimate the whole-body concentration in environmental monitoring programs, and filling a data gap for concentration ratios in cephalopods. Our results help fill data gaps in uptake of nuclear power plant radionuclides in the commercially important Cephalopoda class and add to scarce data on open-ocean nekton in the northwestern Pacific shortly after the Fukushima accident.
\end{abstract}

\section{Introduction}

The Fukushima Daiichi Nuclear Power Plant (FDNPP) accident, which was caused by the combined effect of the March 2011 earthquake and subsequent tsunami, resulted in increased levels of artificial radioactivity in the marine environment to the east of Japan (IAEA, 2015). The radioactive releases, dominated by radiocesium, were transported eastwards in surface water across the midlatitude North Pacific at a speed of 3-7 $\mathrm{km} \mathrm{day}^{-1}\left(3.5-8.0 \mathrm{~cm} \mathrm{~s}^{-1}\right)$ and dispersed widely in the North Pacific within a few years (Aoyama et al., 2013; Smith et al., 2015), which raised concerns about the potential impact on marine biota and human consumers of seafood products.

A large amount of research has been conducted to determine the level of artificial radionuclides in biota samples and to assess the relevant radiological impact on both human and marine species. However, most studies have focused on the concentration of radiocesium in fish (Johansen et al., 2015; Wada et al., 2016), and only a few publications have reported on radionuclides in other marine species (Buesseler et al., 2012; Yu et al., 2015). Few data are available for open-ocean locations as compared to coastal areas, especially from 2011. Filling these data gaps will improve and expand understanding of the dynamics of cesium in the early months following the accident.

Ommastrephes bartramii (neon flying squid) is a migratory squid species that is commercially important, consumed by humans, and is common in both the Pacific Ocean and circumglobal temperate and tropical waters. It feeds near the surface on small fish and is thus a potential accumulator of radiocesium via dietary and water pathways. Moreover, cephalopods have a strong capability to accumulate silver in their bodies (Miramand and Bentley, 1992; Bustamante et al., 2004), potentially indicating uptake of the short-lived $(0.70$ year half-life) Ag-110m released from the FDNPP accident. Similarly, the presence of Cs-134 (2.1 year half-life) in sam- 
ples would also indicate a pathway from FDNPP releases. Therefore, specimens captured at locations in the North Pacific may serve as bioindicators of the presence, strength, and movement of the radioactive signal from the Fukushima Daiichi accident.

This study assessed samples of $O$. bartramii obtained from the northwestern Pacific in November 2011 for a range of artificial and natural radionuclides (Cs-134, Cs-137, Ag-110m, U-238, Ra-226, and K-40). The radiological dose rates and relevant risk levels were determined for the squid, as well as potential dose rates for human consumers of squid. Consistent with international efforts to compile data of radionuclide transfer from environment to biota (Howard et al., 2013), concentration ratios (whole-body to water and whole-body to tissue) were calculated and reported, including those for different age classes of squid.

\section{Materials and methods}

\subsection{Sample collection and analytical procedure}

Thirteen composite samples of $O$. bartramii with a total weight of $126.2 \mathrm{~kg}$ were obtained by bait fishing in open water in the northwestern Pacific. Six sampling locations were selected within the area of $34-39^{\circ} \mathrm{N}$ to $145-149^{\circ} \mathrm{E}$ to investigate eastward deposition and oceanic migration pathways of radionuclide releases from the FDNPP (Fig. 1). To ensure sample mass was sufficient to reach minimum detectable activity (MDA) levels for key radionuclides, composite samples of multiple specimens from the same sampling site were used. For those sites with enough sample mass, the specimens were divided into different composite categories according to body weight. Specimens with a body mass less than $1 \mathrm{~kg}$ were categorized as "small", those between 1 and $2 \mathrm{~kg}$ were categorized as "medium" and those heavier than $2 \mathrm{~kg}$ were categorized as "large". The samples were frozen at $-18^{\circ} \mathrm{C}$ on board for transport to the laboratory for subsequent analysis.

Squid samples were dissected, after thawing, into muscle and gut tissues (other soft tissues including the digestive tract, gills, heart, gonads, and associated glands), dried at $50^{\circ} \mathrm{C}$, and then ashed at $450{ }^{\circ} \mathrm{C}$. The fresh weight and ash weight of the composite samples were recorded. The ash was sealed in cylindrical $75 \mathrm{~mm}$ diameter containers and was then subjected to a planar HPGe (high-purity germanium) spectrometry for detection of gamma-emitting radionuclides.

At each station, $60 \mathrm{~L}$ surface seawater samples, were collected with a submersible pump, stored in polyethylene barrels with acidification to $\mathrm{pH}=2$, and taken back to landbased laboratory for analysis. With carriers of $\mathrm{CsCl}, \mathrm{AgNO}_{3}$, $\mathrm{CoCl}_{2} \cdot 6 \mathrm{H}_{2} \mathrm{O}$, and $\mathrm{FeNH}_{4}\left(\mathrm{SO}_{4}\right)_{2} \cdot 12 \mathrm{H}_{2} \mathrm{O}$ added into the samples, $\mathrm{Ag}-110 \mathrm{~m}$ in the seawater was collected with $\mathrm{AgCl}$ precipitation; Cs-134 and Cs-137 were collected with AMP (ammonium molybdophosphate) precipitation, and ${ }^{58} \mathrm{Co}$,

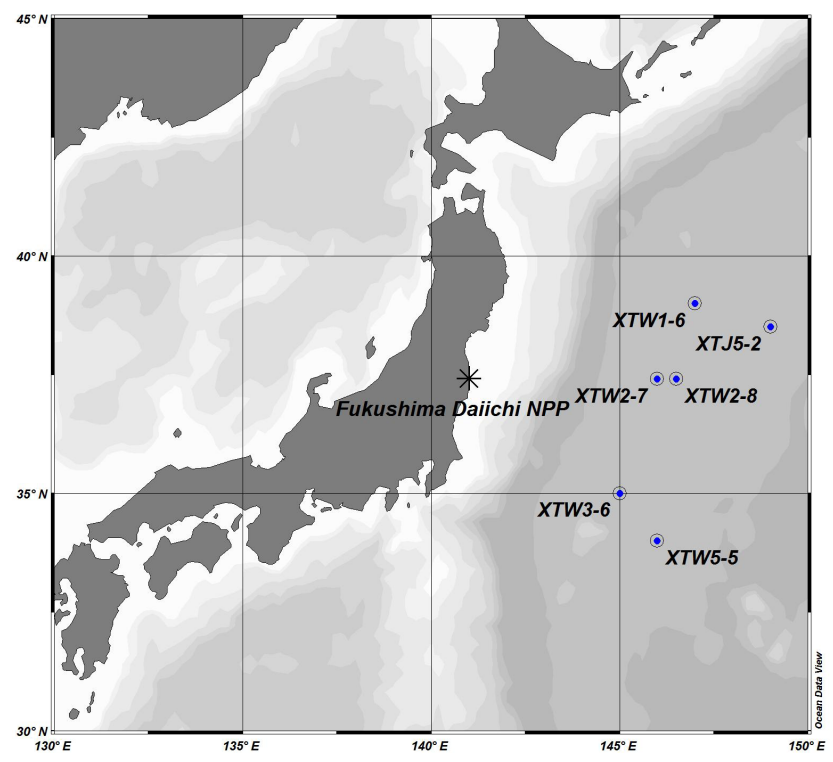

Figure 1. Map of sampling sites.

${ }^{60} \mathrm{Co},{ }^{54} \mathrm{Mn}$ and ${ }^{65} \mathrm{Zn}$ were collected with $\mathrm{Fe}(\mathrm{OH})_{3}$ precipitation sequentially. The precipitate was collected with suction filtration, ashed at $450^{\circ} \mathrm{C}$, weighed, boxed, and then subjected to HPGe spectrometry. Method validation was carried out with standard solutions of Cs-137, Ag-110m, Co-60, Mn54, and Zn-65. Gamma rays from artificial radionuclides (Cs134, Cs-137, Ag-110m, Co-58, Co-60, Mn-54, and Zn-65) and natural radionuclides (K-40, Ra-226, and U-238) were analyzed using a planar HPGe detector (model BE6530 with multi channel analyzer Lynx system, Canberra, USA). Detection efficiencies for the geometry used were $2.8 \%, 2.7 \%$, $2.6 \%, 2.2 \%, 1.5 \%, 2.1 \%, 1.7 \%, 1.5 \%, 4.3 \%$ and $8.5 \%$, for Cs-134, Cs-137, Ag-110m, Co-58, Co-60, Mn-54, Zn-65, K40 , Ra-226, and U-238, respectively. The counting time for each sample was $24 \mathrm{~h}$. Genie 2000 software was used to analyze the respective peaks in the energy spectrum. The concentrations were corrected for decay to the initial date of the nuclear accident on 12 March 2011, when the first hydrogen explosion occurred in Unit 1 of the FDNPP (Wakeford, 2011).

\subsection{Dose assessment for squid}

The ERICA Assessment Tool (version 1.2; Brown et al., 2008) was used with Tier 2 assessment to evaluate the radiological risk to squid from the study areas in 2011. The ERICA tool has the capability to specify organism sizes, and in this study average mass $(1.3 \mathrm{~kg})$ and dimensions (ellipsoid equivalent of $0.3,0.1$, and $0.085 \mathrm{~m}$ for length, width, and height, respectively) from the specimens were used to calculate dose rates. The dimensions of the average $O$. bartramii are very similar to the standard ERICA "pelagic fish" and therefore the dose rates, as calculated by ERICA, are also 
similar. The measured activity concentrations in the whole body of ${ }^{137} \mathrm{Cs},{ }^{134} \mathrm{Cs},{ }^{110 \mathrm{~m}} \mathrm{Ag},{ }^{226} \mathrm{Ra}$, and ${ }^{238} \mathrm{U}$ in the samples were used as dose calculation input. The maximum tissue activity concentrations were used for a more conservative result. As $O$. bartramii are migratory, their radionuclide tissue levels represent an integrated accumulation from recently traversed areas in the open ocean. Since the exact migratory routes are unknown, the external dose rates to the squid were calculated using the average of water radioactivity levels in the study capture region (average of samples across all sampling locations). In this instance, using the average is reasonable because the external dose rates for artificial radionuclides were much lower than the internal dose rates. As a result, variable water activity concentrations had little influence on overall dosages. For internal dose rates for squid, the dose conversion coefficients (DCCs) were calculated within the ERICA tool (Supplement). The occupancy factors were $100 \%$ in water, and weighting factors of internal low beta, internal beta/gamma, and internal alpha were set as 3,1 , and 10 , respectively.

\subsection{Dose from ingesting squid}

Committed effective doses (sievert, Sv) for human consumers of squid were estimated using standard exposure-todose conversion factors (DCFs) for ingestion from the International Commission on Radiological Protection (ICRP) Compendium of Dose Coefficients based on ICRP Publication 60 (ICRP, 1999). Key DCFs are $1.30 \times 10^{-8}$ and $1.90 \times 10^{-8} \mathrm{~Sv} \mathrm{~Bq}^{-1}$ for Cs-137 and Cs-134, respectively (DCFs provided in the Supplement). The factors are multiplied by intake (e.g., $\mathrm{kg} \mathrm{yr}^{-1}$ ) to obtain committed effective doses for the consumer. In this study, the annual intake rate of seafood by an adult consumer is assumed to be $20 \mathrm{~kg} \mathrm{yr}^{-1}$ (consistent with world per capita fish and related seafood consumption; FAO, 2016). As a conservative assumption, the entire $20 \mathrm{~kg} \mathrm{yr}^{-1}$ for a hypothetical consumer is assumed to be sourced from the squid of the study area east of the FDNPP (in practice, only a small percentage of a seafood diet would be sourced from this region). As most dose rates to human consumers of seafood typically come from the natural radionuclide Po-210 ( $\sim 89 \%$; Johansen et al., 2015), the seafood ingestion dose rates here were compared with and without Po-210 to provide a context of the relative influence of the FDNPP accident radionuclides. For this comparison, a generic Po-210 seafood value of $15 \mathrm{~Bq} \mathrm{~kg}^{-1}$ was used based on Hosseini et al. (2010) and consistent with the conservative (lognormal 95th percentile) based on the limited squid data in Carvalho (2011), Heyraud et al. (1994), and Waska et al. (2008).

\subsection{Whole-body concentration ratios}

The water-to-organism whole-body concentration ratio (CR $\mathrm{WB}_{\mathrm{WB}}$ Water $)$ used here is defined as:
$\mathrm{CR}_{\mathrm{WB}}:$ Water $=$

$$
\frac{\text { Whole-body activity concentration (fresh mass) }\left(\mathrm{Bq} \mathrm{kg}^{-1}\right)}{\text { Water activity concentration }\left(\mathrm{BqL}^{-1}\right)} \text {. }
$$

The whole-body activity of a radionuclide was estimated using a mass balance approach (Yankovich et al., 2010) to reconstruct the amount of radionuclide in the whole body of the squid. The whole-body to tissue concentration ratio $\left(\mathrm{CR}_{\mathrm{WB}}\right.$ : Tissue $)$ was estimated as

$\mathrm{CR}_{\mathrm{WB}: \text { Tissue }}=\frac{\sum\left[\begin{array}{c}\text { Tissue }_{t} \text { activity concentration (fresh mass) }_{\text {. }} \text {. } \text { Tissue }_{t} \text { fresh mass fraction }\end{array}\right]}{\text { Tissue }_{t} \text { activity concentration (fresh mass) }_{\text {action }}}$.

\section{Results and discussion}

\subsection{Description of $O$. bartramii specimens}

In total, 98 specimens were obtained from six stations. The mass of the specimens ranged from 118 to $2551 \mathrm{~g}$, with an average of $1347 \mathrm{~g}$. Sixty percent of the specimens weighed 701 to $1700 \mathrm{~g}$. The trunk length of the specimens ranged from 115 to $440 \mathrm{~mm}$ (on average $333 \mathrm{~mm}$ ). Seventy-five percent of the specimens had a length greater than $290 \mathrm{~mm}$ (adult size), suggesting that the majority of the specimens hatched in the winter of 2010 or spring of 2011 and had been living for 8 to 11 months (Wang and Chen, 2005). Combining the estimated age of the squid, and assuming residence in the general region east of Fukushima Prefecture, it can be inferred that most specimens had been accumulating radionuclides since the FDNPP accident. However, a minor proportion (the small size category) may have hatched after the accident and had shorter exposure times.

\subsection{Activity concentrations and concentration ratios (CRs) in squid}

The activity levels of radionuclides in Table 1 indicate that all $O$. bartramii size classes had accumulated radionuclides from FDNPP releases as indicated by Cs-134 and Ag-110m. The squid specimens had a strong capability to concentrate $\mathrm{Ag}$ in their bodies. The maximum activity of $\mathrm{Ag}-110 \mathrm{~m}$ in the whole body of $O$. bartramii reached $9 \mathrm{~Bq} \mathrm{~kg}^{-1}$, as compared to that in water, which was below the MDA of $0.22 \mathrm{~Bq} \mathrm{~m}^{-3}$, indicating a maximum concentration factor higher than $4 \times$ $10^{4}$ for all size classes. The mean CRs for $\mathrm{Ag}-110 \mathrm{~m}$ were calculated as $>(3.0 \pm 0.9) \times 10^{4}$ (Table 2$)$, using the MDA as the activity of seawater in Eq. (1).

Although this estimate contains large uncertainties because of using MDA of $\mathrm{Ag}-110 \mathrm{~m}$ as the water concentration, these $\mathrm{Ag}$ data provide new insights for international researchers. Additionally, they fill a gap because the relevant international database (Wildlife Transfer Parameter Database; http://www.wildlifetransferdatabase.org, last access: 15 November 2018) and IAEA Technical Reports Series No. 422 have entrees for Ag uptake in the mollusk cate- 
gory $\left(3.6 \times 10^{4}\right.$ and $6 \times 10^{4}$, respectively), but none specifically for squid/cephalopods.

The mean $\mathrm{CR}_{\mathrm{WB}}$ values for Cs-134 and Cs-137 in O. bartramii were $6.3( \pm 2.8 \mathrm{SD})$ and $5.6( \pm 2.6 \mathrm{SD})$, respectively. These values are similar to previously published mean concentration factors for Cs ranging from 2 to 14 in cephalopods (Bustamante et al., 2006; IAEA, 1978, 2004; Ishii et al., 1978; Suzuki et al., 1978). The slightly lower $\mathrm{CR}_{\mathrm{WB}}$ in this study is well within the range of expected variation, which can be very high for water-to-organism CR values (e.g., reported CRs for Cs-137 in marine fish range over nearly an order of magnitude; Beresford, 2010). The activity concentration of ${ }^{137} \mathrm{Cs}$ in the research area reached a maximum of $\sim 600 \mathrm{~Bq} \mathrm{~m}^{-3}$ in June 2011 and soon decreased to below $100 \mathrm{~Bq} \mathrm{~m}^{-3}$ (Aoyama et al., 2016). Considering the temporal change of radiocesium in seawater and its relatively short biological half-life ( $\sim 70$ days) in marine organisms, in this study, the CR calculation used mean Cs-134 and Cs-137 seawater activity concentrations $\left(35\right.$ and $36 \mathrm{~Bq} \mathrm{~m}^{-3}$, respectively) from this study's November 2011 sampling, which were similar to the $\sim 50 \mathrm{~Bq} \mathrm{~m}^{-3}$ reported for the same openocean area July-December time frame (Kaeriyama, 2017).

The results also showed that both Cs- 134 and Cs- 137 were concentrated mainly in the muscle of the squid (Fig. 2a). Cesium behaves similarly to potassium in biota and tends to be distributed to the muscle tissue. These results for the openocean real-world conditions are consistent with previous laboratory results of more than $80 \%$ accumulation in the muscle and head of cuttlefish after only $8 \mathrm{~h}$ of exposure to water (Bustamante et al., 2004, 2006). In contrast, for Ag, the openocean squid had $95 \% \mathrm{Ag}$ in the gut versus muscle (Fig. 2b). This result was also consistent with the laboratory cuttlefish, which had $98 \% \mathrm{Ag}$ in the gut following a single spiked feeding and 29 days depuration (Bustamante et al., 2004). From the same study, within the gut, accumulation of $\mathrm{Ag}$ is dominant in the digestive gland.

The smallest squid samples had the highest concentration factors for Cs-134, Cs-137, Ag-110m, and U-238 (Fig. 2). Despite their inferred shorter exposure times (shorter life span), the higher accumulation occurred in the smaller size class compared to the larger size class. These results are consistent with observed Cs depuration rates in juvenile cephalopods (Sepia officinalis) being $\sim 4$ times slower than that of adults, but both relatively fast (adult cuttlefish have a biological half-life of 16 days for Cs and 9 days for Ag; Bustamante et al., 2006). This previous study suggests the radiocesium accumulation and depuration in $O$. bartramii is relatively rapid and that our results primarily reflect recent ( $\sim$ several months) exposure rather than longer-term accumulation.

The levels of activity for ${ }^{58} \mathrm{Co},{ }^{60} \mathrm{Co},{ }^{54} \mathrm{Mn}$ and ${ }^{65} \mathrm{Zn}$ in the samples were all below the MDA $\left(0.22 \mathrm{mBq}\right.$-ash $\left.{ }^{-1}\right)$.

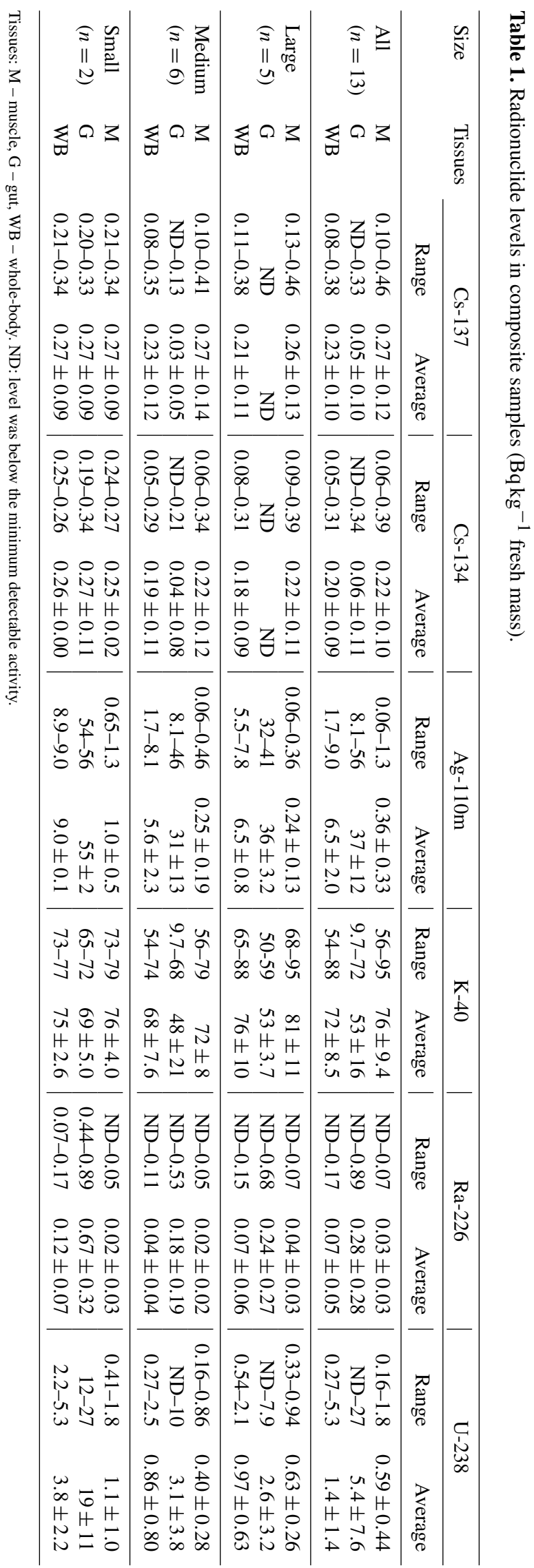



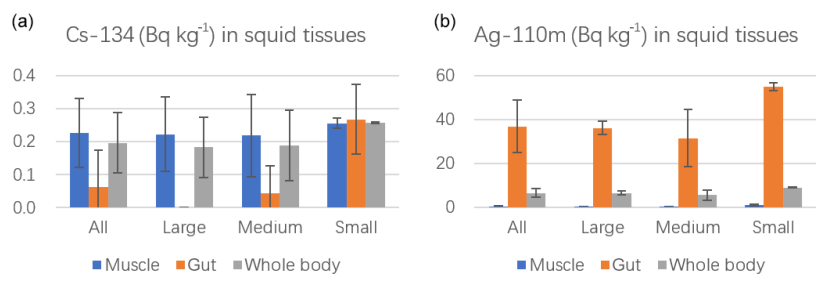

Figure 2. Activity concentrations of Cs-134 (a) and Ag-110m (b) in squid tissues.

\subsection{Whole-body to muscle and whole-body to gut concentration ratios}

Most nonhuman biota radiation-dose-assessing models focus on estimation of dose rates using the whole-body activity concentrations of radionuclides (Brown et al., 2008; United States Department of Energy, 2004). However, muscle tissue (vs. whole-body) is measured in most monitoring programs, which typically focus on seafood tissues consumed by humans. Therefore, there exists a need for whole-body to tissue concentration ratios that allow for estimation of wholebody concentrations from commonly measured tissue data (Yankovich et al., 2010).

The whole-body to muscle and whole-body to gut concentration ratios for radionuclides in squid samples are listed in Table 2. For many radionuclides, the tissue-specific concentrations for the small squids tend to be higher than those for large squids. The uncertainty in the whole-body to gut CRs for Cs-137 and Cs-134 are relatively high because of the comparatively low level and large activity range of radiocesium in gut samples. The CRs presented here are calculated for the nonequilibrium conditions following the accident. This issue is somewhat compensated for by using the average activity concentrations that have accumulated over time, albeit over the relatively short life spans of the squid. Equilibrium conditions are generally not achieved in natural systems, and in our results all CRs should be considered in context. Further research is necessary to obtain a better estimation of the biokinetics of uptake in squid and of the whole-body to gut CRs for Cs-137 and Cs-134.

\subsection{Dose assessment results}

\subsubsection{Dose rates for squid}

The internal radiological dose rates in squid from artificial radionuclides $\left({ }^{110 \mathrm{~m}} \mathrm{Ag},{ }^{134} \mathrm{Cs}\right.$, and $\left.{ }^{137} \mathrm{Cs}\right)$ were collectively much higher than the external dose rates (Fig. 3). This is consistent with the observed accumulation of radionuclides inside the squid body as compared with that in the surrounding seawater. The internal dose rates from FDNPPassociated artificial radionuclides were lower, by 2 orders of magnitude, than those from the natural radionuclides measured in this study. Only approximately $1.4 \%$ of the total

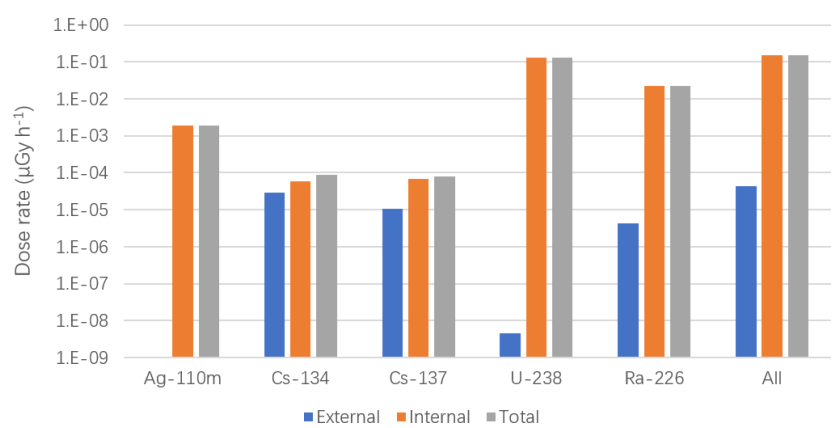

Figure 3. Dose rates $\left(\mu \mathrm{Gy} \mathrm{h}{ }^{-1}\right)$ from measured radionuclides in squid samples.

dose rate is estimated to have come from the FDNPP releases. The total dose rate for squid is $0.15 \mu \mathrm{Gy} \mathrm{h}^{-1}$ from radionuclides measured in this study, and increases to approximately $0.61 \mu \mathrm{Gy} \mathrm{h}^{-1}$ when adding Po-210, a natural radionuclide significant dose contributor in marine organisms (assumes $0.001 \mathrm{~Bq} \mathrm{~L}^{-1}$ in seawater and a generic marine value of $15 \mathrm{~Bq} \mathrm{~kg}^{-1}$ whole-body fresh mass, which is consistent with a general value in Hosseini et al., 2010, and with the lognormal 95th percentile of limited squid Po-210 data; Carvalho, 2011; Heyraud et al., 1994; Waska et al., 2008). When median squid data are used $\left(3 \mathrm{~Bq} \mathrm{~kg}^{-1}\right.$ whole-body fresh mass), the total dose rate is $0.25 \mu \mathrm{Gy} \mathrm{h}^{-1}$. Regardless of using the median or 95th percentile, these dose rates are much lower than the most conservative screening benchmark dose rate of $10 \mu \mathrm{Gy} \mathrm{h}^{-1}$ (Garnier-Laplace, 2008). The dose calculations used the measured activity concentrations in the squid (not CRs), and the calculated dose rates represent a point in time (November 2011) with likely higher doses prior to, and lower doses following, the sampling date. However, the relatively low values indicate that a more detailed (e.g., pulsedynamic uptake) dose calculation is not necessary in this case. Overall, results indicate that the radioactive releases from the Fukushima accident would not have a significant adverse effect on $O$. bartramii individuals or populations living in the study area.

\subsubsection{Dose rates for human consumers of seafood}

From the radionuclides measured in edible squid tissue (muscle), a committed effective ingestion dose of $0.010 \mathrm{mSv}$ (median; minimum $=0.007 \mathrm{mSv}$, maximum $=0.014 \mathrm{mSv}$ ) would have occurred in a hypothetical human consumer of $20 \mathrm{~kg} \mathrm{yr}^{-1}$ of squid from the study area (based on squid captured in November 2011). The doses calculated here are hypothetical and are intended to be conservative overestimates given the unrealistic assumption that all of the consumer's yearly seafood came from the study area. If consumption of Po-210 (from a natural background) is also included, the total dose increases to $0.30 \mathrm{mSv}$, with almost all derived from Po210 using a conservative generic value as described above 
Table 2. Concentration ratios for radionuclides in 2011 following the accident (see text).

\begin{tabular}{llrrrrrr}
\hline CR $^{\mathrm{a}}$ & Size & Cs-137 & Cs-134 & Ag-110m & K-40 & Ra-226 & U-238 \\
\hline WB-M & All & $0.93 \pm 0.28$ & $0.94 \pm 0.30$ & $42 \pm 39$ & $1.0 \pm 0.3$ & $2.8 \pm 1.6$ & $2.4 \pm 1.4$ \\
& Large & $0.82 \pm 0.01$ & $0.82 \pm 0.01$ & $39 \pm 30$ & $0.94 \pm 0.01$ & $2.4 \pm 1.7$ & $1.6 \pm 0.8$ \\
& Medium & $0.85 \pm 0.03$ & $0.86 \pm 0.06$ & $48 \pm 50$ & $0.96 \pm 0.01$ & $2.0 \pm 1.5$ & $2.4 \pm 1.2$ \\
& Small & $1.0 \pm 0.0$ & $1.0 \pm 0.1$ & $10 \pm 5$ & $0.99 \pm 0.02$ & $3.6 \pm 0.5$ & $4.2 \pm 1.7$ \\
\hline WB-G & All & $2.6 \pm 2.5$ & $2.3 \pm 2.4$ & $0.18 \pm 0.02$ & $1.3 \pm 0.2$ & $0.33 \pm 0.29$ & $0.24 \pm 0.03$ \\
& Large & NA & NA & $0.18 \pm 0.01$ & $1.4 \pm 0.2$ & $0.50 \pm 0.43$ & $0.28 \pm 0.01$ \\
& Medium & $4.2 \pm 4.2$ & $3.5 \pm 3.5$ & $0.18 \pm 0.02$ & $1.3 \pm 0.1$ & $0.24 \pm 0.09$ & $0.24 \pm 0.01$ \\
& Small & $1.0 \pm 0.0$ & $1.0 \pm 0.4$ & $0.16 \pm 0.00$ & $1.1 \pm 0.1$ & $0.17 \pm 0.02$ & $0.19 \pm 0.01$ \\
\hline WB-W & All & $6.3 \pm 2.8$ & $5.6 \pm 2.6$ & $>(3.0 \pm 0.9) \times 10^{4}$ & $6.2 \pm 0.7$ & $15 \pm 12$ & $38 \pm 39$ \\
& Large & $5.9 \pm 2.9$ & $5.2 \pm 2.6$ & $>(3.0 \pm 0.4) \times 10^{4}$ & $6.4 \pm 0.8$ & $16 \pm 12$ & $27 \pm 18$ \\
& Medium & $6.3 \pm 3.2$ & $5.3 \pm 3.0$ & $>(2.6 \pm 1.1) \times 10^{4}$ & $5.9 \pm 0.7$ & $9.6 \pm 9.4$ & $24 \pm 22$ \\
& Small & $7.5 \pm 2.5$ & $7.3 \pm 0.1$ & $>(4.1 \pm 0.0) \times 10^{4}$ & $6.4 \pm 0.2$ & $26 \pm 15$ & $(1.1 \pm 0.6) \times 10^{2}$ \\
\hline
\end{tabular}

${ }^{a}$ CR: WB-M represents whole-body to muscle concentration ratios, WB-G represents whole-body to gut concentration ratios, and WB-W represents whole-body to water concentration ratios. ${ }^{b}$ NA: data not available because radioactivity of specific radionuclides in at least one tissue was below the MDA. ${ }^{c}$ Values for Cs-134 and Cs-137 were calculated using mean Cs-134 and Cs-137 seawater activity concentrations of 35.1 and $36.2 \mathrm{~Bq} \mathrm{~m}^{-3}$, and the values for Ag-110m were calculated using the MDA of Ag- $110 \mathrm{~m}$ in seawater $\left(0.22 \mathrm{~Bq} \mathrm{~m}^{-3}\right)$.

Table 3. Ingestion dose estimates for human consumers of the squid in this study ( $\mathrm{Sv} \mathrm{yr}^{-1}$ based on $20 \mathrm{~kg}$ consumption of squid).

\begin{tabular}{lrrrr}
\hline & Minimum & Median & Maximum & This study $\%^{\mathrm{a}}$ \\
\hline K-40 & $6.98 \times 10^{-6}$ & $9.43 \times 10^{-6}$ & $1.18 \times 10^{-5}$ & $3.12 \%$ \\
Ag-110m & $3.36 \times 10^{-9}$ & $2.02 \times 10^{-8}$ & $7.22 \times 10^{-8}$ & $0.01 \%$ \\
Cs-134 & $2.28 \times 10^{-8}$ & $8.36 \times 10^{-8}$ & $1.48 \times 10^{-7}$ & $0.03 \%$ \\
Cs-137 & $2.60 \times 10^{-8}$ & $7.02 \times 10^{-8}$ & $1.20 \times 10^{-7}$ & $0.02 \%$ \\
Ra-226 & & $1.68 \times 10^{-7}$ & $3.92 \times 10^{-7}$ & $0.06 \%$ \\
U-238 & $1.44 \times 10^{-7}$ & $5.31 \times 10^{-7}$ & $1.59 \times 10^{-6}$ & $0.18 \%$ \\
Po-210 & $1.44 \times 10^{-5}$ & $2.92 \times 10^{-4}$ & $1.08 \times 10^{-3}$ & $96.59 \%$
\end{tabular}

\footnotetext{
${ }^{a}$ Based on median activity concentration values in this study (Table 1 data, average of all sizes).
}

${ }^{\mathrm{b}}$ Po-210 from generic published data (Carvalho, 2011; Hosseini et al., 2010).

(Table 3). Of this dose (including Po-210), less than $0.1 \%$ is estimated to have been sourced from the FDNPP. This is consistent with previous findings that natural radionuclides provided far greater dose rates to potential consumers of $\mathrm{Pa}$ cific tuna (Fisher et al., 2013), and even for seafood sourced within a few kilometers of the FDNPP in 2013 (Johansen et al., 2015). The dose contribution from the FDNPP releases for squid consumption of this study are far below the $1 \mathrm{mSv}$ per year recommended constraint for prolonged exposure by the public from nuclear facility releases (ICRP, 1999).

\section{Conclusions}

Elevated levels of Cs-134 and Ag-110m from the FDNPP accident were found in the squid $(O$. bartramii) samples collected from the northwest Pacific in November 2011. The whole-body to water CRs for Ag-110m in squid were found to be as high as $4 \times 10^{4} \mathrm{~L} \mathrm{~kg}^{-1}$ in the smallest samples, with a mean value of $2.95 \times 10^{4} \mathrm{~L} \mathrm{~kg}^{-1}$ in all the samples, indicating that squid was a good bioindicator for $\mathrm{Ag}-110 \mathrm{~m}$ from the FDNPP accident. The radiological dose contribution from the FDNPP releases for squid living in the study area in 2011, and for human consumers of these squid, was far below the recommended dose limits. By comparison, natural radionuclides, particularly Po-210, provided greater dose rates by several orders of magnitude. This study filled a gap in international data of radionuclide transfer from environment to biota (Howard et al., 2013) by providing concentration ratios for several key FDNPP-associated radionuclides in the whole-body and tissues of an open-ocean cephalopod.

Data availability. The data related to this paper are provided in the Supplement and will be submitted to the International Atomic Energy Agency's Marine Information System (MARiS) database.

Supplement. The supplement related to this article is available online at: https://doi.org/10.5194/bg-15-7235-2018-supplement. 
Author contributions. WY contributed to data analysis and modeling of dose to biota; MPJ contributed to the modelling of dose to biota and human consumers, and data interpretation; WY and MPJ wrote the manuscript with support from LL; JH helped supervise the project; WM contributed to sample collection. All authors discussed the results and contributed to the final manuscript.

Competing interests. The authors declare that they have no conflict of interest.

Acknowledgements. This study was partially supported by the Scientific Research Foundation of the Third Institute of Oceanography, SOA (2015010), the Northwestern Pacific Marine Environmental Monitoring Project, the Coordinated Research Project (CRP K41017), and Regional Cooperative Agreement Project (IAEA/RCA RAS7028) of the International Atomic Energy Agency (IAEA), the National Key Scientific Instrument and Equipment Development Project (2016YFF0103905), the International Organizations and Conferences Project of the State Oceanic Administration of China, and the Public Science and Technology Research Project of the Ocean (201505005-1).

Edited by: Manmohan Sarin

Reviewed by: four anonymous referees

\section{References}

Aoyama, M., Tsumune, D., and Hamajima, Y.: Distribution of ${ }^{137} \mathrm{Cs}$ and ${ }^{134} \mathrm{Cs}$ in the North Pacific Ocean: impacts of the TEPCO Fukushima-Daiichi NPP accident, J. Radioanal. Nucl. Ch., 296, 535-539, 2013.

Aoyama, M., Hamajima, Y., Hult, M., Uematsu, M., Oka, E., Tsumune, D., and Kumamoto, Y.: ${ }^{134} \mathrm{Cs}$ and ${ }^{137} \mathrm{Cs}$ in the North Pacific Ocean derived from the March 2011 TEPCO Fukushima Dai-ichi Nuclear Power Plant accident, Japan. Part one: surface pathway and vertical distributions, J. Oceanogr., 72, 53-65, 2016

Beresford, N. A.: The transfer of radionuclides to wildlife, Radiat. Environ. Bioph., 49, 505-508, 2010.

Brown, J. E., Alfonso, B., Avila, R., Beresford, N. A., Copplestone, D., Prohl, G., and Ulanovsky, A.: The ERICA tool, J. Environ. Radioactiv., 99, 1371-1383, 2008.

Buesseler, K. O., Jayne, S. R., Fisher, N. S., Rypina, I. I., Baumann, H., Baumann, Z., Breier, C. F., Douglass, E. M., George, J., and Macdonald, A. M.: Fukushima-derived radionuclides in the ocean and biota off Japan, P. Natl. Acad. Sci. USA, 109, 5984-5988, 2012.

Bustamante, P., Teyssié, J. L., Danis, B., Fowler, S. W., Miramand, P., Cotret, O., and Warnau, M.: Uptake, transfer and distribution of silver and cobalt in tissues of the common cuttlefish Sepia officinalis at different stages of its life cycle, Mar. Ecol.-Prog. Ser., 269, 185-195, 2004.

Bustamante, P., Teyssié, J. L., Fowler, S. W., and Warnau, M.: Assessment of the exposure pathway in the uptake and distribution of americium and cesium in cuttlefish (Sepia officinalis) at differ- ent stages of its life cycle, J. Exp. Mar. Biol. Ecol., 331, 198-207, 2006.

Carvalho, F. P.: Polonium $\left({ }^{210} \mathrm{Po}\right)$ and lead $\left({ }^{210} \mathrm{~Pb}\right)$ in marine organisms and their transfer in marine food chains, J. Environ. Radioactiv., 102, 462-472, 2011.

Garnier-Laplace, J., Copplestone, D., Gilbin, R., Alonzo, F., Ciffroy, P., Gilek, M., Aguero, A., Bjork, M., Oughton, D. H., and Jaworska, A.: Issues and practices in the use of effects data from FREDERICA in the ERICA Integrated Approach, J. Environ. Radioactiv., 99, 1474-1483, 2008.

FAO (Food and Agriculture Organization of the United Nations): The State of World Fisheries and Aquaculture 2016 (SOFIA) Contributing to food security and nutrition for all, Rome, 200 pp., 2016.

Fisher, N. S., Beaugelin-Seiller, K., Hinton, T. G., Baumann, Z., Madigan, D. J., and Garnier-Laplace, J.: Evaluation of radiation doses and associated risk from the Fukushima nuclear accident to marine biota and human consumers of seafood, P. Natl. Acad. Sci. USA, 110, 10670-10675, https://doi.org/10.1073/pnas.1221834110, 2013.

Heyraud, M., Cherry, R. D., Oschadleus, H. D., Augustyn, C. J., Cherry, M. I., and Sealy, J. C.: Polonium-210 and Lead-210 in edible molluscs from near the Cape of Good Hope: Sources of variability in polonium-210 concentrations, J. Environ. Radioactiv., 24, 253-272, 1994.

Hosseini, A., Beresford, N. A., Brown, J. E., Jones, D. G., Phaneuf, M., Thorring, H., and Yankovich, T.: Background dose-rates to reference animals and plants arising from exposure to naturally occurring radionuclides in aquatic environments, J. Radiol. Prot., 30, 235-264, 2010.

Howard, B. J., Beresford, N. A., Copplestone, D., Telleria, D., Proehl, G., Fesenko, S., Jeffree, R. A., Yankovich, T. L., Brown, J. E., Higley, K., Johansen, M. P., Mulye, H., Vandenhove, H., Gashchak, S., Wood, M. D., Takata, H., Andersson, P., Dale, P., Ryan, J., Bollhofer, A., Doering, C., Barnett, C. L., and Wells, C.: The IAEA handbook on radionuclide transfer to wildlife, J. Environ. Radioactiv., 121, 55-74, 2013.

IAEA (International Atomic Energy Agency): The Radiological Basis of the IAEA Revised Definition and Recommendations Concerning High-level Radioactive Waste Unsuitable for Dumping at Sea, in: IAEA-TECDOC-211, IAEA, Vienna, 1978.

IAEA (International Atomic Energy Agency): Sediment distribution coefficients and concentration factors for biota in the marine environment, IAEA, Vienna, 2004. IAEA (International Atomic Energy Agency): The Fukushima Daiichi Accident, IAEA, Vienna, Austria, 2015.

ICRP (International Commission on Radiological Protection): Protection of the Public in Situations of Prolonged Radiation Exposure, Publication 82, International Commision on Radiologial Protection, Ottawa, ON, 1999.

Ishii, T., Suzuki, H., and Koyanagi, T.: Determination of trace elements in marine organisms, 1: Factors for variation of concentration of trace element, B. Jpn. Soc. Sci. Fish., 44, 155-162, 1978

Johansen, M. P., Ruedig, E., Tagami, K., Uchida, S., Higley, K., and Beresford, N. A.: Radiological dose rates to marine fish from the Fukushima Daiichi accident: the first three years across the North Pacific, Environ. Sci. Technol., 49, 1277-1285, 2015.

Kaeriyama, H.: Oceanic dispersion of Fukushima derived radioactive cesium: a review, Fish. Oceanogr., 26, 99-113, 2017. 
Miramand, P. and Bentley, D.: Concentration and distribution of heavy metals in tissues of two cephalopods, Eledone cirrhosa and Sepia officinalis, from the French coast of the English Channel, Mar. Biol., 114, 407-414, 1992.

Smith, J. N., Brown, R. M., Williams, W. J., Robert, M., Nelson, R., and Moran, S. B.: Arrival of the Fukushima radioactivity plume in North American continental waters, P. Natl. Acad. Sci. USA, 112, 1310-1315, 2015.

Suzuki, Y., Nakahara, M., and Nakamura, R.: Accumulation of cesium-137 by useful mollusca, Nippon Suisan Gakk., 44, 325329,1978

United States Department of Energy: RESRAD-BIOTA: a tool for implementing a graded approach to biota dose evaluation. ISCORS Technical Report 2004-02: DOE/EH-0676, USDOE, Washington DC, 2004.

Wada, T., Fujita, T., Nemoto, Y., Shimamura, S., Mizuno, T., Sohtome, T., Kamiyama, K., Narita, K., Watanabe, M., Hatta, N., Ogata, Y., Morita, T., and Igarashi, S.: Effects of the nuclear disaster on marine products in Fukushima: An update after five years, J. Environ. Radioactiv., 164, 312-324, 2016.
Wakeford, R.: And now, Fukushima, J. Radiol. Prot., 31, 167-176, 2011.

Wang, R. and Chen, X.: The world ocean economic squid resources and Fisheries, China Ocean Press, Beijing, 2005.

Waska, H., Kim, S., Kim, G., Kang, M. R., and Kim, G. B.: Distribution patterns of chalcogens (S, Se, Te, and $\left.{ }^{210} \mathrm{Po}\right)$ in various tissues of a squid, Todarodes pacificus, Sci. Total Environ., 392, 218-224, 2008.

Yankovich, T. L., Beresford, N. A., Wood, M. D., Aono, T., Andersson, P., Barnett, C. L., Bennett, P., Brown, J. E., Fesenko, S., and Fesenko, J.: Whole-body to tissue concentration ratios for use in biota dose assessments for animals, Radiat. Environ. Bioph., 49, 549-565, 2010.

Yu, W., He, J., Lin, W., Li, Y., Men, W., Wang, F., and Huang, J.: Distribution and risk assessment of radionuclides released by Fukushima nuclear accident at the northwest Pacific, J. Environ. Radioactiv., 142, 54-61, 2015. 